\title{
Scoundrel or Über-Lieutenant? The Vice Presidency of Dick Cheney
}

\author{
Jody C. Baumgartner
}

In this essay I evaluate the vice presidency of Dick Cheney. Although roundly criticized throughout his tenure in the mainstream media and popular press for the policies he advocated and presumably helped implement, his secretive nature, his tendency to subvert standard bureaucratic procedures, and exercising undue influence over the president, there is actually no objective framework within which to evaluate vice presidents. After reviewing criticism about Cheney's tenure in office, I offer an alternative view based on what presidents expect from their vice presidents. From this perspective, in his role as loyal lieutenant for George W. Bush, we are forced to conclude that Cheney was actually a successful vice president.

Vice President Dick Cheney has been the subject of numerous stories in the popular press which point to his supposed abuses of power, influence over the president, secretiveness, and more. His list of "sins" includes catering to energy interests in the design of Bush's energy policy; refusing to produce documents dealing with the crafting of this policy; playing a central role in the decision to invade Iraq; unfairly awarding no-bid contracts to his previous employer, Haliburton; helping the administration execute and justify torture in the War on Terror; and orchestrating the outing of CIA agent Valerie Plame (Dubose and Bernstein 2006).

In addition, although he is one of the least public of modern vice presidents, Cheney has been one of the most ridiculed in popular culture. From the popular perception of Cheney as Darth Vader to the barrage of jokes made at his expense by late night talk show hosts and on the Internet, he is one of the most reviled vice presidents in recent memory, perhaps surpassing even Dan Quayle.

This might appear to make the task of assessing Cheney's vice presidency fairly simple. He has been the most powerful vice president (VP) in the history of the republic and probably ranks as one of the most controversial as well. But even if it were agreed that Cheney was culpable for all of the acts mentioned above, a question still remains: how do we evaluate vice presidents? Even a generation or two ago, this question might be met with a derisive, "why bother?" The prevailing view was that the vice presidency

I wish to thank Dr. Robert Thompson of East Carolina University for the extremely valuable comments made throughout the preparation of this manuscript.

JODY C BAUMGARTNER is an assistant professor of political science at East Carolina University.

The American Review of Politics, Vol. 29, Fall, 2008: 235-252

(c)2008 The American Review of Politics 
was at best irrelevant. Woodrow Wilson once wrote that "the chief embarrassment in discussing [the vice president's] office is that in explaining how little there is to be said about it one has evidently said all there is to say" (Wilson 1898, 240-41).

There are actually few objective criteria by which to evaluate an individual's performance as vice president. One can, to be sure, look to the VP's two constitutional functions, that of successor to the president and presiding officer of the Senate. But even casual observers of the presidency understand that these two functions no longer define the job of modern vice presidents. The fact that VPs have played an increasingly important, if informal, role in their presidents' administrations is well documented (Goldstein 1982; Light 1984; Hatfield 1997; Baumgartner 2006a). So how to evaluate the VP's performance in these informal roles?

Since there is no existing framework within which to evaluate a vice presidency, I assess the Cheney vice presidency through two separate, descriptive lenses. The first can be thought of as a policy or a legal-constitutional perspective and corresponds roughly to the body of criticism leveled against him during his tenure. The second derives from what is now a fairly well-developed, if informal, way in which both presidents and VPs understand the job of the vice presidency (Goldstein 1982; Light 1984; Hatfield 1997; Baumgartner 2006a). This can be thought of as a practitioner's approach and is based on a set of norms that guide VPs during their tenure. In this view, a modern VP serves a constituency of one: the president. The VP's main function beyond his or her constitutional duties is to assist the president in whatever way the president sees fit.

\section{The Cheney Vice Presidency: The Conventional View}

One would be hard-pressed to find many defenders of Dick Cheney's tenure as vice president. He has been the subject of criticism by a plethora of political and media elites. In most cases these critics disagree either with the substance of the policies Cheney has advocated or the way he has gone about promoting or implementing these policies, or both. He is charged with being secretive, manipulative, and, perhaps most damning of all, exercising too much influence over the president. Some have gone so far as to suggest he acted in an unconstitutional or extra-constitutional manner (Reynolds 2007).

Much has also been made of the fact that Cheney advocates an expansive view of executive branch power, especially with regard to foreign policy (Savage 2007; Hayes 2007; Dubose and Bernstein 2006). This is the result of his experience serving as President Gerald Ford's chief of staff from 1975-77 (Walsh 2006), where he emerged "absolutely committed to 
the idea of restoring the powers of the presidency" (Gilmore and Kirk 2007). This commitment appears to be drive Cheney's secrecy and his tendency to subvert normal bureaucratic procedures.

Cheney seems to have an almost principled belief in secrecy (Purdum, 2006; Savage 2007, 85-118). For example, during his tenure the work of the office of the vice presidency (OVP) was stored in large safes, talking points were often labeled as "Treated as: Top Secret/SCI" (sensitive compartmented information), and he has refused to disclose the names or size of his staff. "The vice president's office [went] to unusual lengths to avoid transparency" (Gellman and Becker 2007a). His refusal to release the names of the individuals consulted during meetings of the National Energy Policy Development Group in 2001 was one such example, believing that confidentiality of those involved is necessary for candid advice to be offered to the executive.

Cheney also refused to hand over newly de-classified documents to the National Archives and Records Administration. In June of 2007 he made the controversial statement that the OVP was exempt from the executive order governing the handling of such material because it was not part of the executive branch. Although Bush administration officials proceeded to claim the executive order did not apply to the OVP, the matter underscored his propensity to withhold information (Baker 2007; Duffy 2007b; Reynolds 2007). Cheney's "dark, secretive mind-set" can even be seen in the way in which he reacted to the accidental shooting of a fellow hunter in February of 2006. In the aftermath he did not report the incident to members of the national press, did not inform the president until 36 hours afterwards, and refused to speak with reporters about the incident until he granted an exclusive interview with Fox News' Brit Hume (Thomas 2006).

Cheney's desire to restore presidential power also seems to relate to his habit of operating outside normal bureaucratic procedures. One analyst suggested Bush's approach to governance was based on "control over the structures and processes of government, using administrative means to achieve" his ends (Aberbach 2005, 144-45). If this assessment is fair, it is in part due to a "deep practical knowledge of the federal bureaucracy" which positioned Cheney to have what many think is an undue amount of influence over many policies.

In November of 2001 Cheney's lawyer drafted a secret memo that Cheney circulated to a handful of people with "emphatic instructions to bypass staff review." The memo, stripping suspected foreign terrorists of access to courts, was formalized and signed into a military order by Bush less than an hour later. Secretary of State Colin Powell and national security adviser Condoleezza Rice, neither of whom knew anything about the directive, were reportedly incensed (Gellman and Becker 2007a). Powell and 
Rice were also kept out of the loop for over two years while Cheney and several lawyers associated with the administration formulated legal opinions about international security law as it related to the distinction between interrogation and torture. This eventually led to highly controversial administration policy (Gellman and Becker 2007b).

At times Cheney's shortcuts seemed to border on illegal or unconstitutional. In March of 2007, former chief of staff to Vice President Dick Cheney, Lewis "Scooter" Libby Jr., was convicted of perjury, obstruction of justice, and lying to the FBI in an investigation regarding the leak of CIA officer Valerie Plame's identity in the summer of 2003 (Lewis 2007). Many believed Libby was covering for Cheney, who had directed him to leak part of a classified CIA report in order to undermine the credibility of Plame's husband and critic of the Iraq War, Joseph Wilson (Duffy 2007a; Toobin 2007).

Perhaps the most damning criticism leveled against Cheney has been that he exercised too much influence over the president. The advisory role of the VP is a feature of the modern vice presidency (Light 1984), but many believe he took this role too far. For example, in January of 2007, former Vice President Walter Mondale sharply criticized Cheney's role in the build up to the war in Iraq, suggesting that Cheney "stepped way over the line" (Yee 2007).

Cheney seems to have had a hand in setting the course in many Bush policies. He was, for example, reportedly influential in an early Bush decision to reverse his promise to lower carbon-dioxide emissions (Lemann 2001). The recommendations of his energy task force became the administration line. He was reportedly influential in the decision to not make concessions to Republican Senator Jim Jeffords, resulting in his defection from the party (Becker and Gellman 2007b). He chaired the budget review board responsible for the 2001 budget tax cuts. He has also, presumably, "served as gatekeeper for Supreme Court nominees, [and] referee of Cabinet turf disputes" (Becker and Gellman 2007a), led the warrentless wiretapping efforts (Savage 2007), and much more. In addition, Cheney, through his advocacy and his efforts in obtaining and interpreting data from the CIA about weapons of mass destruction, led the push to invade Iraq in 2003 (Woodward 2004).

Cheney was so influential it became popular to assume or imply that it was he, not Bush, making the decisions (Dubose and Bernstein 2006; Savage 2007). But Cheney "is not, by nearly every inside account, the shadow president of popular lore. Bush has set his own course, not always in directions Cheney preferred" (Gellman and Becker 2007a). The most prominent example of this was when Bush began advocating a constitutional amendment banning gay marriage in the run up to the 2004 campaign. Cheney, 
whose daughter Mary is gay, largely avoided the subject throughout the campaign (Baumgartner 2006a, 133).

In fact, most believe his influence declined throughout his second term (Sanger and Schmitt 2006; Gellman and Becker 2007a; Duffy 2007a). This was presumably the result of several factors, including the Iraq War, the 2006 mid-term elections which gave Democrats a majority in Congress, the Libby conviction, and his hunting accident. The Bush administration's more pragmatic approach to a variety of issues, including negotiations with North Korea, permitting courts to review the wiretapping of terrorism suspects, and making "rhetorical nods to issues such as global warming and income inequality" (Abramowitz 2007) are often cited as evidence of the decline in Cheney's influence.

In all, critics would likely agree that Cheney's vice presidency was a failure. They would point to failed or bad policy decisions, the fact that he quietly subverted normal policy procedures, and his near-usurpation of presidential power. In fact, several have suggested that some of Cheney's actions were criminal. One writer suggested that his refusal to turn over declassified documents was unconstitutional (Reynolds 2007). In 2007 Dennis Kucinich introduced a proposal in the House to impeach Cheney, charging he had manipulated intelligence prior to the invasion of Iraq (Abrams 2007). From this perspective, Cheney has been a less than stellar public servant.

This conclusion seems to be reflected in the public view of Dick Cheney. Data show that as his tenure progressed the public took an increasingly unfavorable view toward him. For example, his public approval ratings declined steadily throughout his tenure, bottoming out at just over twenty percent by 2008. This might be not be surprising given Bush's declining approval ratings, since some evidence suggests that presidential and vice presidential approval and favorability track fairly closely with each other (Cohen 2001a, 2001b). Figure 1 tracks the percentage of people responding "excellent" or "pretty good" to a Harris Poll question, "How would you rate the job [Vice President Dick Cheney / President George Bush] is doing: excellent, pretty good, only fair, or poor?” from February 2001 through February 2008.

By comparison, Gallup Poll numbers indicate that Al Gore's job approval ratings hovered around the mid-sixty percent range throughout his second term; again, these figures are comparable to Bill Clinton's ratings (Cohen 2001a). Cheney's favorability ratings have also declined throughout his two terms. According to NBC News/Wall Street Journal polls, from January, 2001 to June, 2008 those who had a positive view of Cheney declined from 49 to 23 percent; those who had a negative view increased from 16 to 58 percent. Here again Gore's numbers show a decline throughout his two terms, but not nearly as sharply (Cohen 2001b). If we evaluate 
Figure 1. Job Approval Ratings:

\section{Dick Cheney and George W. Bush, 2001-2008}

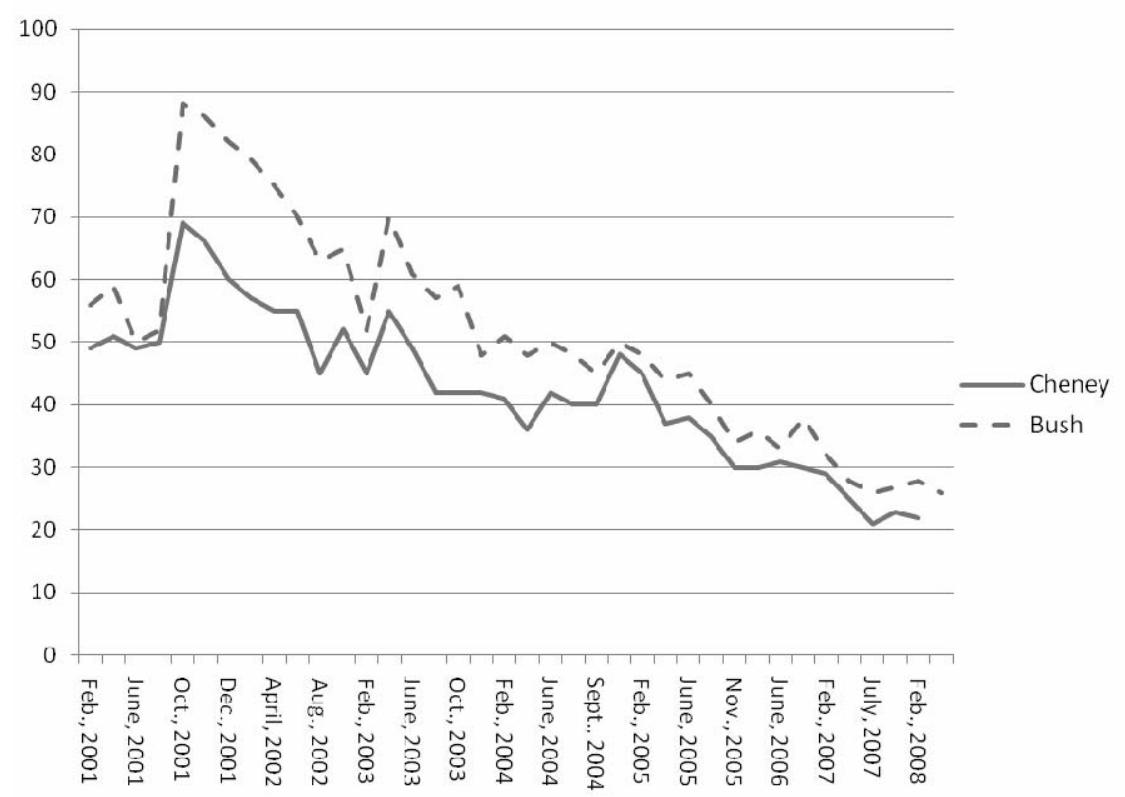

Source: Polling Report.com.

VPs on how they are perceived by the public, Cheney fares rather poorly here also.

\section{The Cheney Vice Presidency: An Alternative View}

An alternative approach to evaluating a vice presidency would be to look to what presidents look for in a VP. This is a realpolitik view of the office, grounded in practice and precedent. From this perspective the VP serves a constituency of one: the president. This view is not without intellectual foundation. From the inception of the office there has been discussion about expanding the role of the VP (see Learned, 1912, for a review), including reforming the office in order to provide the president with assistance (Rossiter 1948). The actual foundation for this approach, however, is based in the transformation of the office in the past four decades (Light 1984; Baumgartner 2006a).

Since the vice presidential candidacy of Lyndon Johnson, it is standard practice for presidential and vice presidential candidates to discuss the role of the VP prior to or immediately after the election. Nelson Rockefeller, for 
example, accepted Gerald Ford's offer of the vice presidency contingent on access to the president and a meaningful role in domestic policy development. Walter Mondale also had a fairly well defined agreement with Jimmy Carter about his role in the administration. Al Gore and Bill Clinton discussed what Gore's role would be in some detail (Baumgartner 2006a, 13933). In addition, since Walter Mondale left office most VPs have offered advice to their successors. For example, Dan Quayle met with Dick Cheney after the election to discuss what to expect. Certain norms about the job have developed and are now propagated.

According to these norms, VPs are expected to act as loyal assistants. This maxim can be expanded as follows. ${ }^{1}$ First, and most important, is that loyalty from the VP is assumed (Cronin 1982, 339-40; Light 1984, 233-34). The VP is expected to toe the presidential line, so to speak, in public. Disagreements, if any, should be kept private. This also means advice given to the president is given in confidence. Relatedly, the VP should never upstage the president. The American people should never be confused about who the president is. If advice given by the VP is taken, the VP should not take credit for it.

In their role as loyal assistants, VPs must "share the dirty work" (Light 1984, 234). This may involve any number of activities, including campaigning for members of Congress, promoting the president's policies on the road, dealing with members of Congress, and so on. VPs must, in other words, be willing to actively promote the president's agenda. Holding Cheney's actions up against this description suggests a completely different assessment of his vice presidency. Below, I review his tenure according to his performance in the formal and informal roles of modern vice presidents. Throughout, it can be seen that in his role as loyal assistant, Cheney was a model VP.

\section{The Cheney Vice Presidency: Formal Roles}

Formally, the Constitution charges the VP with succeeding the president in the event of presidential vacancy, and presiding over and breaking tie votes in the Senate. In terms of the former, while Cheney has his detractors, few would claim he is less than capable and qualified to assume presidential office. He has a master's degree in political science and brought a total of 21 years of experience in national government office to the vice presidency. He was the first VP to become "acting president" under the 25th Amendment, on June 29, 2002, when President Bush temporarily (from 7:09 a.m. until 9:24 a.m.) transferred power to Cheney prior to undergoing a colonoscopy (Lipper 2002). ${ }^{2}$ 
Since the Mondale vice presidency VPs have not regularly presided over the Senate, primarily due to their increased responsibilities in the executive branch. Cheney was no exception to this trend, presiding over the Senate only rarely. He did, however, cause a minor stir in this capacity. During a photo opportunity following a session of the Senate, Cheney got into a heated exchange with Vermont Senator Patrick Leahy (D) over the former's ties to Haliburton and Bush's judicial nominees. Cheney ended the exchange with a well-publicized profanity (Dewar and Milbank 2004).

VPs are also charged with breaking tie votes in the Senate. Because the Senate was so closely divided during his first term, Cheney broke more tie votes than any VP since Richard Nixon (see Table 1). From the time of his inauguration through the spring of 2001 there were an equal number of Democrats and Republicans in the Senate. In May of 2001 Vermont Republican Senator James Jeffords switched his party affiliation from Republican to independent and announced he would caucus with the Democrats. This gave the Democrats a 51-49 majority (Reaves 2001). Cheney remained attentive to business of the Senate through the 2002 mid-term elections (when Republicans regained a majority) in order to be on hand and advance Bush's policies if his vote was needed.

In 2005 Cheney inserted himself into a controversy in the Senate regarding confirmations to the federal bench. With Democrats refusing to vote on Bush's judicial selections, Republicans threatened to amend Senate procedures and ban filibusters in such cases. VPs are generally loathe to interfere too much in the business of the Senate (Baumgartner 2006a, 11516), but Cheney broke convention and publicly announced his support for this so-called "nuclear option." In the end moderate members of the Senate reached an agreement and his support proved unnecessary (Hurt 2005).

In addition to their constitutional roles VPs have statutory duties, including acting as ex-officio member of the Smithsonian Board of Regents, naming cadets to the military academies, appointing senators to various independent commissions, and being responsible for the nuclear button in the event the president is incapacitated (Gillon 1997). The most important statutory role of the VP is his membership in the National Security Council (NSC; History of the National Security Council 1997). VPs typically attend full meetings of the NSC and have been known to chair in the president's absence (Baumgartner 2006a, 116-17).

Much has been written about Cheney's role in foreign and security policy during the Bush administration. Shortly after Bush's inauguration it was reported that Cheney wanted to chair meetings of NSC principals, which include the secretaries of Defense and State, the director of the CIA, and the chairman of the Joint Chiefs. A National Security Presidential Directive in February killed this idea, formalizing National Security Adviser 
Table 1. Tie Votes in the Senate, Dick Cheney, 2001-2008

Date Legislation

April 3, 2001 Grassley Amendment 173 on bill for prescription drugs for seniors

April 5, $2001 \quad$ Hutchison Amendment 347 on marriage penalty tax break

May 21, 2002 Motion to table Allen Amendment 3406 to provide mortgage assistance for employees who are separated from employment

April 11, 2003 Agreeing to House Budget Resolution 95 Conference report

May 15, 2003 Nickles Amendment 664 to modify the dividend exclusion provision

May 23, 2003 Jobs and economic growth H.R.2, to provide for reconciliation pursuant to section 201 of the concurrent resolution on the budget for fiscal year 2004

Dec. 21, 2005 Motion to concur in House Amendment with an amendment to S.1932 to provide for reconciliation of the concurrent resolution on the budget for fiscal year 2006

March 13, 2008 Motion to reconsider Senate Amendment 4189 to Senate Con. Res. 70, to repeal section 13203 of Omnibus Budget Reconciliation Act of 1993 by restoring Alternative Minimum Tax rates in effect prior to that time

From: "Votes to Break Ties in the Senate." The U.S Senate. Available at senate.gov/pagelayout/ reference/four_column_table/Tie_Votes.htm.

Condoleezza Rice's role in chairing most of these meetings. Like Gore before him, Cheney was present at all NSC meetings, but some have suggested that his close relationship with Donald Rumsfeld contributed to a certain dysfunction at these meetings (Perlez 2001; Walsh 2004; Mitchell 2005, 144).

While Gore had a national-security adviser (Leon Fuerth), Cheney informally assembled what some have referred to as a rather large "shadow NSC.” Importantly, while this staff were kept abreast of what the NSC was doing, the opposite was not true. Like Cheney, they were skilled in the ways of bureaucracy, tight-lipped, and, often at odds with the NSC itself. Colin Powell's chief of staff Lawrence Wilkerson suggested this was one factor explaining the influence Cheney had over foreign and security policy (Dreyfuss 2006).

Finally, modern VPs are sometimes appointed by their presidents to take the lead in a particular policy area. Although the trend since Mondale has been to avoid such assignments, a recent and relatively high-profile example was Gore's "National Performance Review" ("re-inventing government"). Similarly, Cheney was tasked with creating a national energy policy 
shortly after his inauguration. The National Energy Policy Development Group held their meetings that spring, releasing their report in May. As noted previously, Cheney came under immediate and intense criticism by Democrats for his secretive conduct of the meetings. Democrats and other groups charged that the task force met with a number of energy industry executives, including those from Cheney's former employer, Haliburton, to the exclusion of other (e.g., environmental) groups. This fueled speculation about corruption, since the VP did not make the list of participants public. It has since been revealed that several industry executives, including Enron's Kenneth Lay, did meet with the task force (Milbank and Blum 2005).

\section{The Cheney Vice Presidency: Informal Roles}

Throughout the twentieth century VPs have taken on several informal responsibilities acting as presidential surrogate. These include ceremonial duties, such as attending funerals. VPs also perform a range of diplomatic duties abroad. In addition, presidents turn to VPs to perform political tasks, including campaigning and promoting the president's programs. Finally, VPs since Nelson Rockefeller have served, in varying degrees, in an advisory role to their presidents. According to most observers, this is the hallmark of the modern vice presidency (Goldstein 1982; Light 1984; Baumgartner 2006a).

Because he was so active in the day-to-day affairs of the administration, Cheney performed fewer ceremonial duties than did most modern VPs. He did, however, do his part. In July of 2003 he commissioned the aircraft carrier U.S.S. Ronald Reagan (Cheney 2004) and later marked the 50th anniversary of the Korean War armistice by laying a wreath at the Tomb of the Unknowns in Arlington Cemetery (Associated Press 2003). Of course he attended several funerals on behalf of the administration, for example, the services for King Fahd of Saudi Arabia in 2005 (Washington Wire 2005).

As an illustration of how controversial Cheney was, Cheney was quietly un-invited to the funeral of Minnesota's Democratic Senator Paul Wellstone in 2002. That fall he had campaigned for St. Paul Mayor Norm Coleman, who was challenging Wellstone for his Senate seat. After the senator, his family, and several campaign aides were killed in a plane crash, it was announced by the White House that Cheney would represent the president at the funeral. Wellstone's family announced security for the VP would be too difficult to arrange and accommodate and they would prefer the VP not attend (DeFrank and Bazinet 2002). But "sources close to the Wellstone family quietly confirmed that the family considered the vice president's presence inappropriate” (Baumgartner 2006a, 120). 
Vice presidents also perform a diplomatic role, acting as presidential envoy to other countries. Some trips are made for ceremonial purposes (e.g., Cheney's attendance at King Fahd's funeral), while others are for the purpose of discussing relations between the U.S. and the country in question. Cheney made fewer of these trips than his predecessors (Baumgartner 2006a, 121-22), and most were related to the Middle East: the war in Iraq, the Israeli-Palestinian conflict, Iran, or the war on terror (LaFranchi 2002; Knowlton 2004; Harris, Steele, and Tait 2006; Squires 2007; Baker 2007; Krieger and Keinon 2008). Cheney also made three trips to Iraq from 2005 to 2008, visiting troops on each occasion (Stevenson 2005; Cheney Urges Political Unity in Iraq Visit 2008; Dombey and Ward 2008).

Modern VPs also play a political role in the administration (Goldstein 1982), campaigning and promoting the president's policies. Here Cheney was very energetic. In 2000 he pushed himself so hard in the post-election campaign he suffered a mild heart attack (his fourth). In the last week of the 2004 campaign he visited over 30 cities (Kennerly 2004). In each campaign he defended Bush's positions while vigorously attacking the opponent. In 2004 he suggested that John Kerry was "weak and vacillating on issues of national security," questioned his patriotism by reminding listeners that he discarded his war medals in a 1971 antiwar protest, and claimed a Kerry victory would encourage terrorists (Thomas 2004, 99; Pomper 2005, 56).

Cheney also performed well in both presidential debates. The debate with Joe Lieberman was a generally congenial affair, displaying both men's command of domestic and foreign policy (Baumgartner 2006, 100-102). His debate with John Edwards was rather low key, with the exception of a minor stir caused by the comment Edwards made about Cheney's gay daughter (Ceaser and Busch 2005, 131). Cheney was also active in campaigning for Republican candidates in mid-term elections (Baker 2006). In 2002, he raised $\$ 10$ million for approximately 60 Republican candidates (Sandalow 2002), and in 2006 he "held 114 campaign events across the country and raised more than $\$ 40$ million for the G.O.P. cause” (Allen and Carney 2006).

Cheney was also "the point man for the president's policies on Capitol Hill” (Baumgartner 2006a, 126). He worked behind the scenes with the principals, often excluding even his staff (Kessler 2004). He was the first VP to have an office in the House of Representatives (during his first term; Schmitt 2000) and attended meetings of the House leadership (Alvarez and Schmitt, 2001). His knowledge of Washington and his experience as Minority Whip in the House were extremely helpful in promoting the president's agenda. He reportedly played a key role in helping pass Bush's third tax cut through in May of 2003 (Kessler 2004) and the Central American Free Trade Agreement (O’Rourke 2005). 
Cheney differs from other modern VPs in that public appearances were rare, but he did occasionally "go public" to promote the administration's policy agenda. He often appeared on Fox News' "Hannity and Colmes" as well as on Hannity's talk radio program (Baumgartner 2006a, 126), and did grant an occasional interview with select reporters (Feldman 2006; Purdum 2006). He was vocal in defending the administration's Iraq policy, becoming, perhaps appropriately, a lightning rod of sorts in that regard (Schmitt 2005).

The most consequential development in the evolution of the modern vice presidency is the inclusion, in varying degrees, of VPs in the presidential decision making process (Light 1984). Modern VPs are now included in most policy discussions and have access to the presidential paper flow. In this regard, Cheney held "an unrivaled portfolio across the executive branch" (Gellman and Becker, 2007a). His influence was, like that of all VPs, dependent on trust by the president (Light 1984). Thus it is instructive to trace their relationship to the beginning. Cheney had known Bush since he had worked as Secretary of Defense in George H. W. Bush's administration. Though not especially close, Cheney donated money to the younger Bush's gubernatorial campaign in 1994. After Cheney accepted his position as CEO of Haliburton they met occasionally at the governor's mansion, discussing a wide range of subjects. These meetings made business sense for Cheney, whose political insights benefitted the ambitious but less experienced Bush. After Bush's reelection in 1998 Cheney was invited to Austin with other experts to discuss national security policy, and their visits became more frequent as Bush ramped up his presidential bid (Hayes 2007, 274-75). One could assume it was during these meetings that Bush's trust in Cheney grew.

Bush's reliance on Cheney became evident soon after he won the Republican nomination in 2000, when Cheney was asked to serve as head of the VP search committee. Although he claimed that he was not interested in the job, as the summer progressed there were signs that he was Bush's favored selection. On July 25 Bush announced that Cheney would be his running mate. Further illustrating Bush's trust, Cheney began work on the presidential transition soon after the election (Gellman and Becker 2007a), starting and administering a privately funded transition team (since they could not receive office space from the government until the election was decided; Freedman 2000). Cheney's influence can be seen in Bush's selections for several key Cabinet positions in his first administration, including Cheney's old mentor, Donald Rumsfeld, his colleague and friend from the Ford administration, Paul O’Neill, and Colin Powell (Hayes 2007, 301).

Continuing a practice set by Walter Mondale, Cheney met with the president at a weekly lunch (Gellman and Becker 2007a), but these meetings were something of a formality. The two actually met several times per day, 
in addition to morning NSC meetings (Baumgartner 2006a, 132). Cheney also had access to all domestic and foreign policy meetings. While this fact has been cited by some as evidence of Cheney's power (Gellman and Becker 2007a), all VPs since Walter Mondale have had this carte blanche access. Cheney also met frequently with other top administration officials, and it was often the case that when others came to the White House expecting to meet with the president, they found themselves meeting the VP instead. British Prime Minister Tony Blair met with Cheney for an hour before meeting with Bush on a state visit. John McCain met with Cheney instead of Bush to discuss campaign finance (Baumgartner 2006a, 132). During his first term Cheney met with Colin Powell, Donald Rumsfeld, and Condoleezza Rice on a weekly basis (Alvaraez and Schmitt 2001) and frequently with other cabinet secretaries as well. Bush reportedly told one Republican senator, "When you're talking to Dick Cheney, you're talking to me. When Dick Cheney's talking, it’s me talking” (Lemann 2001).

Cheney's influence, however, was exercised behind the scenes; he wielded "power with few fingerprints" (Kessler 2004). He vetted numerous policy options before they reached the president and steered lower-level policy discussions around options he favored. Some administration officials deferred to Cheney's position out of respect, others, out of fear. Cheney held "the view . . . that the vice president should be the chief of staff in effect, that everything should run through his office” (Becker and Gellman 2007a). He was not alone in this view: his understanding with Bush was that he would be, in the words of Dan Quayle, "surrogate chief of staff" (Gellman and Becker 2007a). In addition, Cheney was almost always the last person that Bush talked to before a major decision was made (Becker and Gellman 2007a).

Since neither Cheney nor Bush discuss their relationship, it would be difficult to prove Cheney's voice was decisive in any given policy area. Many of the administration's decisions and policies were those Cheney advocated. But authoritative sources confirm that Bush was indeed the final decision maker (Gellman and Becker 2007a). This said, Cheney was certainly quite influential in many policy areas.

\section{Conclusions}

So what to make of the Cheney vice presidency? Clearly he has been a controversial figure. Equally clearly, he seemed unconcerned about this fact. This may be because he is not seeking the presidency. He noted, "my image might be better out there . . if I spent more time as a public figure trying to improve my image, but that's not why I'm here" (Purdum 2006). This perhaps, captures the essence of the matter. Although Cheney advocated, and 
forcefully pushed his own policy agenda, as this review suggests, he viewed his job in terms of how he could help his president, and in this respect he succeeded. Importantly, there is little indication that Cheney acted as a lone agent, and much to suggest that Bush either explicitly or implicitly approved of his actions.

It is probable that some of the criticism Cheney drew negatively affected Bush's approval ratings. Of course, other VPs (e.g., Agnew) in the modern era have also been used as a lightning rod for the policy decisions for the administration (Baumgartner 2006a). Cheney's advocacy of the Iraq War, the Libby conviction, and the manner in which he dealt with the press all reflected poorly on Bush. Much of the criticism leveled against him, however, came in the line of duty to his president. For example, expanding presidential power, especially with respect to lack of transparency, seems to have been a goal Bush shared; the administration's policy regarding torture could not have been Cheney's alone. In other words, most of his actions were at least tacitly supported by the president, who was, both nominally and in practice, in charge.

It is also likely his mission of expanding presidential power may have backfired, since several court rulings have gone against the administration. This may have the effect of hamstringing future presidents in certain regards. For example, the Supreme Court ruled in 2006 that alleged terrorists could not be tried in military tribunals, a policy Cheney advocated (Gellman and Becker 2007b).

Of course, this review has left one very large question unanswered, namely, what should be the role of the vice president? Having already taken what I believe is a rather unorthodox view of the Cheney vice presidency, I am inclined to leave this question to others. At its root, I believe, it is a normative question, even if soundly based in constitutional principles and law. I base this belief in the voluminous amount of scholarship (in the Neustadtian tradition) that questions whether presidents should be more or less powerful. Lacking any definitive answer to this question, I am hesitant to tackle the vice presidential version.

My sense is there will be some sort of backlash against the "imperial" vice presidency of Dick Cheney in the next administration. Al Gore was, however, the most powerful VP in American history prior to Dick Cheney, and to my knowledge no voice was raised in objection to the amount of power and influence he held. Could this be because more people (scholars, the media, the public) approved of Clinton/Gore's policies? In other words, if Gore had exercised the same amount of influence that Cheney did, would he have been as reviled? Of course, the difference between the amount of influence each had may be a difference in kind rather than in degree. Even admitting that, one is left with the problem of how to define a VP's job such 
that a standard can be applied to all vice presidents. Thus, I am reminded that most scholarly essays end with calls for future research. In this case the need is quite clear.

What does the future hold for the office? While the next VP (Joe Biden or Sarah Palin) will probably not be as influential as Cheney was, the modern vice presidency has become institutionalized. This is not news, but it does suggest the possibility that a future VP could play as significant a role in their president's administration as did Cheney. Modern VPs have virtually full access to the policy process. Beyond this, much, perhaps most, depends on how much influence the president is willing to grant the VP. In other words, the key variables are not necessarily the individual or the office, but rather the president he or she serves.

\section{NOTES}

${ }^{1}$ See Purcell (2001) for a concise version, taken from George H.W. Bush's memoirs, of this description of the vice president's job.

${ }^{2}$ The 25th Amendment was not invoked when George H. W. Bush served as acting president while President Reagan underwent surgery on July 13, 1985 (Baumgartner 2006a, 114).

\section{REFERENCES}

Aberbach, Joel D. 2005. The Political Significance of the George W. Bush Administration. Social Policy and Administration 39(2):130-149.

Abramowitz, Michael. 2007. Cheney's Influence Lessens in Second Term. Washington Post, February 20, p. A5.

Abrams, Jim. 2007. Debate on Cheney Impeachment Averted. Washington Post, November 6. washingtonpost.com/wp-dyn/content/article/2007/11/06/AR2007110601451. html.

Allen, Mike, and James Carney. 2006. Exclusive Interview: Cheney on Elections and Iraq. Time, October 19. time.com/time/printout/0,8816,1548061,00.html.

Alvaraez, Lizzette, and Eric Schmitt. 2001. Cheney Ever More Powerful as Crucial Link to Congress. The New York Times, May 13, p. A1.

Baker, Peter. 2006. Cheney Back Delivering the Grim Campaign Speech. Washington Post, October 8, p. A14.

Baker, Peter. 2007. Cheney Defiant on Classified Material. Washington Post, June 22, p. A1.

Baumgartner, Jody. 2006a. The American Vice Presidency Reconsidered. Westport, CT: Praeger.

Baumgartner, Jody. 2006b. The Second-best Choice? Vice-presidential Candidate Qualifications in the Traditional and Modern Eras. White House Studies 6:179-195.

Baker, Aryn. 2007. Cheney in the War Zone. Time, March 12, p. 19. 
Becker, Jo, and Barton Gellman. 2007a. A Strong Push from Backstage. Washington Post, June 26, p. A1.

Becker, Jo, and Barton Gellman. 2007b. Leaving No Tracks. Washington Post, June 27, p. A1.

CBS News. 2004. Richard (Dick) Cheney Timeline. CBSNews.com, www.cbsnews.com/ htdocs/politics/inauguration/cheney.pdf.

Ceaser, James W., and Andrew E. Busch. 2005. Red Over Blue: The 2004 Elections and American Politics. Lanham, MD: Rowman \& Littlefield.

Cheney, Dick. 2004. Remarks by the Vice President at the Ronald Reagan Presidential Library and Museum. Whitehouse.gov. March. whitehouse.gov/news/releases/2004/ 03/20040317-3.html.

Cheney Urges Political Unity in Iraq Visit. 2008. USA Today. March 17. usatoday.com/ news/world/iraq/2008-03-17-iraq-us-cheney N.htm.

Cohen, Jeffrey E. 2001a. The Polls: Popular Views of the Vice President: Vice Presidential Approval. Presidential Studies Quarterly 31: 142-49.

Cohen, Jeffrey E. 2001b. The Polls: Popular Views of the Vice President and Vice Presidential Favorability. Presidential Studies Quarterly 31: 349-57.

Cronin, Thomas E. 1982. Rethinking the Vice-Presidency. In Rethinking the Presidency, ed. Thomas E. Cronin. Boston: Little, Brown \& Company.

Curl, Joseph. 2007. Cheney to Visit Mideast Allies. The Washington Times, May 9, p. A4.

DeFrank, Thomas M., and Kenneth R. Bazinet. 2002. Cheney not Welcome at Wellstone Memorial. Daily News, October 30, p. 26.

Dewar, Helen, and Dana Milbank. 2004. Cheney Dismisses Critic With Obscenity, Clash with Leahy About Halliburton. Washington Post, June 25, p. 4.

Dombey, Daniel, and Andrew Ward. 2008. Oil Tops Cheney’s Middle East Tour Agenda. Financial Times, March 16. ft.com/cms/s/0/d132d1e2-f3a2-11dc-b6bc0000779fd2ac.html?nclick check=1.

Dreyfuss, Robert. 2006. Vice Squad. The American Prospect, April 17.

Dubose, Lou, and Jake Bernstein. 2006. Vice: Dick Cheney and the Hijacking of the American Presidency. New York: Random House.

Duffy, Michael. 2007a. Cheney’s Fall From Grace. Time, March 8. time.com/time/nation/ article/0,8599,1597226,00.html.

Duffy, Michael. 2007b. The Cheney Branch of Government. Time, June 22. time.com/ time/nation/article/0,8599,1636435,00.html.

Feldmann, Linda. 2006. 14 hours, really, with Dick Cheney. Christian Science Monitor, October 17, p. 20.

Freedman, Dan. 2000. Cheney Opens Office as Base for Transition. Milwaukee Journal Sentinel, November 30, p. A16.

Gellman, Barton, and Jo Becker. 2007a. A Different Understanding with the President. Washington Post, June 24, p. A1.

Gellman, Barton, and Jo Becker. 2007b. Pushing the Envelope on Presidential Power. Washington Post, June 25, p. A1.

Gillon, Steven M. 1997. A New Framework: Walter Mondale as Vice President, P. 146 in At the President's Side: The Vice Presidency in the Twentieth Century, ed. Timothy Walch. Columbia MO: University of Missouri.

Gilmore, Jim (reporter, producer), and Michael Kirk (writer, producer, director). 2007. Interview: David Gergen. Frontline. Posted October 16. pbs.org/wgbh/pages/ frontline/cheney/interviews/gergen.html. 
Goldstein, Joel K. 1982. The Modern American Vice Presidency: The Transformation of a Political Institution. Princeton, NJ: Princeton University.

Grimaldi, James V., and Jacqueline Trescott. 2001. Secrecy Pervaded Smithsonian on Small's Watch. Washington Post, June 21, p. C01.

Harris, Paul, Jonathan Steele, and Robert Tait. 2006. US Attempt to Pull Iraq Back from the Brink. The Observer, November 26, p. 37.

Hatfield, Mark O. 1997. Vice Presidents of the United States, 1789-1993. Washington, DC: U.S. Government Printing Office.

Hayes, Stephen F. 2007. Cheney: The Untold Story of America's Most Powerful and Controversial Vice President. New York: HarperCollins.

History of the National Security Council, 1947-1997. 1997. Office of the Historian, U.S. Department of State. whitehouse.gov/nsc/history.html\#summary.

Hurt, Charles. Cheney Pledges Filibuster Override. The Washington Times, April 23. washingtontimes.com/national/20050422-114701-8401r.htm.

Kennerly, David Hume. 2004. Dick Cheney’s Final Assault Across America. The Digital Journalist, November. dirckhalstead.org/issue0411/dis_kennerly.html.

Kessler, Glenn. 2004. Impact from the Shadows: Cheney Wields Power with Few Fingerprints. Washington Post, October 5, p. A1.

Knowlton, Brian. 2004. Cheney’s Davos Trip Is Just 2nd Appearance Overseas. International Herald Tribune. January 23, p. 3.

Krieger, Hilary Leila, and Herb Keinon. 2008. Bush: 'We Expect Parties to Uphold Their Obligations.' The Jerusalem Post. March 11, p. 1.

LaFranchi, Howard. 2002. Cheney’s Mideast Reality Check. Christian Science Monitor, March 20, 94(80):1.

Learned, H. B. 1912. Some Aspects of the Vice Presidency. Proceedings of the American Political Science Association. 9:162-177.

Lemann, Nicholas. 2001. The Quiet Man. The New Yorker, May 7, p. 56.

Lewis, Neil J. 2007. Libby Guilty of Lying in C.I.A. Leak Case. New York Times, March 6, p. A1.

Light, Paul C. 1984. Vice-Presidential Power: Advice and Influence in the White House. Baltimore: Johns Hopkins University.

Lipper, Tamara. 2002. President Cheney? Newsweek, July 8, 140(2):8.

Milbank, Dana. 2000. The Chairman and the CEO. Washington Post, December 24, p. A1.

Milbank, Dana, and Justin Blum. 2005. Document Says Oil Chiefs Met With Cheney Task Force. Washington Post, November 16, p. A1.

Mitchell, David. 2005. Making Foreign Policy: Presidential Management of the Decision-making Process. Burlington, VT: Ashgate.

O’Rourke, Lawrence M. 2005. CAFTA Unsettled in House. Sacramento Bee, July 28, p. D1.

Perlez, Jane. 2001. Directive Says Rice, Bush Aide, Won’t Be Upstaged by Cheney. The New York Times, February 16, p. A5.

Polling Report. N/D. Vice President Dick Cheney: Job Ratings. Pollingreport.com, pollingreport.com/C.htm\#Cheney\%20JOB.

Pomper, Gerald. 2005. The Presidential Election: The Ills of American Politics after 9/11. In The Elections of 2004, ed. Michael Nelson. Washington, DC: CQ Press.

Purcell, L. Edward. 2001. George Herbert Walker Bush (b. 1924). In Vice Presidents: A Biographical Dictionary, ed. L. Edward Purcell. New York: Checkmark Books.

Purdum, Todd S. 2006. A Face Only a President Could Love. Vanity Fair, June, p. 124. 
Reaves, Jessica. 2001. What Jeffords' Switch Means for the 2002 Campaigns. Time, May 24, time.com/time/nation/article/0,8599,127913,00.html.

Reynolds, Glenn H. 2007. Is Dick Cheney Unconstitutional? Northwestern University Law Review Colloquy 102:110-116.

Rossiter, Clinton L. 1948. The Reform of the Vice-presidency. Political Science Quarterly 63:383-403.

Sandalow, Marc. 2002. Cheney’s Disappearing Act: Vice President to Surface-and Give Speech-in S.F. San Francisco Chronicle, August 4, p. A1.

Sanger, David E., and Eric Schmitt. 2006. Cheney's Power No Longer Goes Unquestioned. New York Times, September 10. nytimes.com/2006/09/10/washington/ 10cheney.html.

Savage, Charlie. 2005. Court Backs Cheney on Energy Meetings. The Boston Globe, May 11, p. A3.

Savage, Charlie. 2007. Takeover: The Return of the Imperial Presidency and the Subversion of American Democracy. New York: Back Bay Books.

Schmitt, Eric. 2000. The 43rd President: The Vice president-Elect. New York Times, December 16, p. A1.

Schmitt, Eric. 2004. Cheney Unusually Visible as He Mends Fences in Europe. The New York Times, January 27, p. A3.

Schmitt, Eric. 2005. After the War: The Administration. The New York Times, July 25, p. A10.

Squires, Nick. 2007. Cheney Visits an Australia Roiled by Guantanamo, Iraq. Christian Science Monitor, February 22, 99(60):4-10.

Stevenson, Richard W. 2005. Cheney, in Surprise Visit, Hails Iraq Efforts. The New York Times, December 19, p. A12.

The Associated Press. 2003. Cheney Marks Anniversary with Wreath at Arlington. St. Petersburg Times, July 27. sptimes.com/2003/07/27/Korea/Cheney_marks_ annivers.shtml.

Thomas, Evan. 2005. Election 2004: How Bush Won and What You Can Expect in the Future. New York: Public Affairs.

Thomas, Evan. 2007. The Shot Heard Round the World. Newsweek, February 26, p. 24.

Toobin, Jeffrey. 2007. Comment: Verdicts. The New Yorker, March 19, p. 59.

Walsh, Kenneth T. 2004. In The Eye of The Storm. U.S. News and World Report, April 5, 136(11):29.

Walsh, Kenneth T. 2006. The Cheney Factor. U.S. News \& World Report, 15 January, p. 40-48.

Washington Wire. 2005. Wall Street Journal, August 5, p. A4.

Wilson, Woodrow. 1989. Congressional Government: A Study in American Politics, 13th ed. Boston, MA: Houghton Mifflin.

Woodward, Bob. 2004. Plan of Attack. New York: Simon \& Schuster.

Yee, Daniel. 2007. Mondale: Cheney is out of Line. StarTribune.com, January 19. Available at http://www.startribune.com/587/story/947072.html. 